\title{
OCTOBER 28, 1918. REWRITING OR OVERLAYERING OF CZECH HISTORICAL MEMORY?
}

\section{ABSTRACT}

October 28, 1918 is the Czech Republic state holiday whose historical memory is a combination of Czech, Czechoslovak, and Central European 20th century history. On this date in Prague, the Czechoslovak Republic was proclaimed, and its first law was passed. The events in Prague were part of the complex and long-lasting fall of the Habsburg monarchy and the creation of its successor states, in which national, state-forming, and ideological (e.g. Bolshevist) aspects were interwoven. Accordingly, we can speak of Czech, Slovak, (Czecho)-German, Hungarian, Polish and Rusinian October 28s. As the only state holiday (with an interruption in the period of the Nazi occupation), it was intended to act as the chief connecting and uniting holiday for the CSR state identification; it was to strengthen 'Czechoslovakism'. Its annual celebrations were associated with a series of rituals not only for the Czechs themselves but, over time and to varying degrees, also for the other nationalities living in the CSR: primarily the Slovaks and the Rusinians were seen to truly accept the ceremonial day. The Nazi occupying power was successful only insofar as it forced October 28, 1918 into private crypto-commemoration, while naturally it was celebrated by the resistance movement. The Communist regime tried to 'rewrite' October 28 in the spirit of social revolution, treating it as the precursor of its political victory after 1945 and in particular after 1948. It was to be commemorated as the Nationalization Day (of key industries in 1945) in direct relation with the liberation of the CSR by the Soviet Army (alone!) in 1945. Finally, the Communists attempted to force it out of the collective memory through its official non-observance as a remembrance of 1918, and by designating it, in 19751988, as a significant, but still a working, day. However, the memory of the Establishment of the Republic refused to be suppressed, as was evidenced in a particularly strong manner in the demonstrations of 1968, 1988 and, crucially, of 1989. All attempts at 'rewriting' this holiday in the spirit of ideologies failed in the end, although during the 1938 /39 to 1989 /92 period spontaneous public celebrations were successfully repressed to a significant degree by means of the political manipulation of Czech/Czechoslovak history.

\section{KEYWORDS:}




\section{RENEWING OUR POLITICAL INDEPENDENCE IN THE FORM OF A DEMOCRATIC REPUBLIC IS THE NATURAL OUTCOME AND CONTINUATION OF OUR DEVELOPMENT.}

TGM, WORLD REVOLUTION, 1925, P. 582.

October 28 is recorded in the Czech historical memory as a holiday with its own emotional history. Connected with it are a number of events which define the Czech / Czechoslovak history of the 20th century, and these events have their own timespace ${ }^{1}$, which holds their place in history ${ }^{2}$. It is surprising therefore that up to now only little attention has been paid to this date as a site of memory. Of course a great deal of historical literature has addressed this occasion, but as a specific historical event ${ }^{3}$, and not as a site of memory. It has been explicitly treated by D. Hájková ${ }^{4}$ and in two contributions in the extensive monograph Memory of Places, Events and Personalities: History as Identity and Manipulation ${ }^{5}$. In it the Martin Declaration of 1918 is commemorated, interpretable, as we will show, as the "Slovak October $28^{6}$ ", but the decisive October 28 itself - from the Slovak standpoint - only contextually ${ }^{7}$. In fact, it is precisely October 28, 1918 which is the site of memory in both senses of the title of the mentioned monograph - it is a site of memory of national and state identity, but also the place of attempts at manipulation of history. So let us try to recapitulate its history and to interpret its memory - or memories?

\footnotetext{
'The term 'time-space' here designates the complex of causal and functional relations bonded to given historical events and creating their active context; in this study time-space is defined by Czechoslovak/Czech legislation. The inspirational sources of this concept include E. Husserl, Přednášky k fenomenologii vnitřního časového vědomí, translator V. Špalek and W. Hansel, Rychnov n. K. 1996 and S. W. Hawking, A Short History of Time. Translator V. Karas. Prague, 2003.

${ }^{2}$ As historical here we designate its perception in the arrow of (historical) time, its historical interpretations running against the flow of time, knowing the results of a historical event, and the placement of the event in a pseudo-teleological context which from our standpoint gives sense to past events. See H. von Wright, Explanation and Understanding. London 1974.

${ }^{3}$ Literature on this day is very extensive, both memoirs and historical. See the comments to this text.

${ }^{4}$ D. Hájková, "28 ř́jen a jeho podoby" [ October 28 and its forms ], in 1918 - model komplexního transformačního procesu?, [1918 - model of the complex transformation process?], ed. by L.Kostrbová, J. Malínská et al. Prague 2010, pp. 219-232. This study, like the interpretation of Z. Kárník, relates to our present study but emphasizes different aspects of recollections of that day. See also I. Šedivý, "Victory Day 28. October 1918? La naissance de la Tchécoslovaquie, le contexte de la Grande Guerre et ses consequences”, in: La Tchécoslovaquie sismographe de l'Europe au XXe Siécle, ed. by A. Marés et al. Paris 2009, pp. 35-41.

${ }^{5}$ Pamèt míst, událostí a osobností: historie jako identita a manipulace, M. Hlavačka, A. Marés, M. Pokorná et al. Prague 2011.

${ }^{6}$ E. Boisserie, “Quelques réflections sur les querelles d'interpretation de la Déclaration du Martin du 30. octobre 1918”, in:Pamèt mist, událostí a osobností: historie jako identita a manipulace, M. Hlavačka, A. Marés, M. Pokorná et al. Prague 2011, p. 71-82.

D. Kováč, "Štátne sviatky v Slovenskej republike ako 'miesta pamäti”, in : Pamět míst, událostí a osobností: historie jako identita a manipulace, M. Hlavačka, A. Marés, M. Pokorná et al. Prague 2011, p. 105-118.
} 
P. Nora in his famed work, Les Lieux de Mémoire ${ }^{8}$ defines memory, in association with M. Halbwachs ${ }^{9}$, as the "sediment" of history, i.e. as that which in the flow of events and historical time remains stable, unchanged. His words from the introduction to Les Lieux de Mémoire: "History is always a problematic and incomplete reconstruction of that which no longer exists. Memory is a phenomenon which is always current, a pilgrimage undertaken in an eternal present; history is an illustration of the past ${ }^{10}$ ". From the 1980s, when Nora developed his concept of historical memory, there have emerged other successive explanations, differentiations and simplifications, and therefore a certain shadowing ${ }^{11}$. It would seem, however, that Nora's original definition of memory has not lost its literal meaning ${ }^{12}$; from this also flows the question the title of this paper formulates: is it possible to rewrite history, or does memory simply overlay itself?

\section{OCTOBER 28, 1918 AND ITS VARIANTS}

October 28 was declared a state holiday right away in 1919 by a special law (law $555 / 1919 \mathrm{Sb}$. of October 14, 1919). This way, October 28 became an annual national holiday. In its justification report, the government bill was substantiated thusly: "On October 28 the Czechoslovak Republic was founded. Therefore, this day stands among the most significant dates in the history of the nation and the state of Czechoslovakia, and this date will always be remembered in a spirit of passionate enthusiasm." The diction reveals revolutionary euphoria and emotionality, but the real situation was by far not as simple as this formulation claims - and so in a number of respects at once.

In the first place, October 28 was not the only date that can be associated with the origin of the Czechoslovak Republic. Other days connected with the whole birth process of the new country can also be considered - and these dates also appeared in the discussions of that time. Chronologically perceived, there was discussion about October 14, 1918, when the agreed upon state was announced by the assembly of the provisional Czechoslovak government, and when the Czechoslovak Republic was publicly declared after a general strike at the Council of Czech and Moravian Towns,

\footnotetext{
${ }^{8}$ P. Nora, Le Lieux de memoire I - III, 5. sv., Paris 1984-1992.

${ }^{9}$ M. Halbwachs, La mémoire collective, Paris 1950

${ }^{10}$ P. Nora, "Mezi pamětí a historii", transl. by H. Thein, Cahiers du CEFRES No. 13, Prague 1998, p. 9.

"See Milan Hlavačka, “Místa paměti a jejich 'místo' v historickém a společenském 'provozu”, in: Pamět míst, událostí..., p. 10-21.

${ }^{12}$ Cf. A. Assmann, Erinnerungsräume. Formen und Wandlungen des kulturellen Gedächtnisses. München 1999, p. 130nn; E. Domańska, Pamięć. etyka i historia. Poznań 2000, p. 22; N. Masslowski, J. Šubrt et al., Kolektivní pamět'. K teoretickým otázkám. Prague 2014.
} 
and when part of the domestic resistance ${ }^{13}$ also voted for this declaration. Another date was October 18, the publication date of the Washington Declaration, which proclaimed the democratic character of the future Czechoslovak state and which followed the recognition of the Czechoslovak National Council as the supreme representative of the national interest and the basis for the future Czechoslovak government by the French (June 29, 1918) and British (August 9, 1918) governments. This was followed by its direct recognition as the provisional Czechoslovak government by the government of USA on September 3, 1918, Japan (September 9, 1918), and Italy (October 3, 1918). Theoretically, November 14 could also be taken into consideration, when the Revolutionary National Assembly officially declared the formation of the Czechoslovak Republic, the overthrow of the Habsburg-Luxembourg dynasty and the election by acclamation of Masaryk as the President of the Republic, and also formed the first Czechoslovak government. In fact, in the days of October, the dynasty had never been stripped of its throne in a direct manner ${ }^{14}$.

T.G. Masaryk himself defended the October 28 date by stating that the agreed upon Reparations Commission had determined this day as the date from which the CSR was an allied country and that it was "accepted by the whole nation as the beginning of our independence" because this happened "on our own land" 15 The public (and nation-wide) declaration of the new independent state was - as Masaryk mentioned - a necessary condition for the emergence of a new state in the opinion of many constitutional experts.

Furthermore, the formulation that this was a holiday shared by the entire nation was pretty much a political proclamation, because there was a number of "October $28 \mathrm{~s}$ " at the same time. However, it was chosen as the symbolic moment, supported by legal opinion and as if destined to become the uniting element forming a common Czechoslovak state consciousness. Of course, the period's ideology and terminology made use of the word "national" when speaking of Czechoslovakism, rather than the obviously more precise Czecho-Slovakism ${ }^{16}$.

The first October 28 State Holiday law remained in effect until 1925. The new Law on Holidays and Holiday and Memorial Days in the Czechoslovak Republic (no. 65/1925 of April 3, 1925), which placed October 28 among five CSR memorial days (along with July 5, the feast day of the Slav Apostles St. Cyril and Methodius,

${ }^{13}$ J. Strúbrný, TGM a 28. ř́ijen. Prague 1938.

See Z. Kárník, Malé dějiny Czechoslovak 1871-1939. Prague 2008, p. 43.

15 T. G. Masaryk, Svètová revoluce. Prague 1925, p. 467-468.

${ }^{16}$ See Constitutional document of the Czechoslovak Republic from February 29, 1920, section I, $\$ 4$ "State citizenship in the Czechoslovak Republic is single and united”. See also section V, \$106. para. 2. http://www.psp.cz/ docs/texts/constitution_1920.html (accessed: May 26, 2015). 
September 28, of St. Wenceslas, July 6, of Master Ján Hus, and May 1), left October 28 as the only state holiday. The law outlined the guidelines for its celebration since no such rules had been laid out before this: all regulations valid for Sundays would henceforth also apply to this date; $\$ 3$ gave local offices the authority to organize their own "dignified outdoor celebration of this day" and made its infringement punishable by a fine of up to 10000 crowns or imprisonment for up to one month. These regulations for the celebrations applied to public offices, business companies, and schools. ${ }^{17}$

The memorial days and their significance, and among them the special meaning of October 28 as a national holiday, were set out by the Justification Report on the proposed law:

As (memorial) days proposed by the Government include July 5, the day of St. Cyril and Methodius, the Apostles to the Slavs, who laid the foundations for Slav writing; September 28, St. Wenceslas Day, on which, after long centuries the nation knew its savior, and whose name has grown to become the symbol of our national independence, St. Wenceslas' crown; as well as July 6, dedicated to the memory of Master Ján Hus, on which date a great part of our nation recognizes the man who, by his memorial struggle for the nationalization of Prague University and freedom from that medieval universalism which was so dangerous for smaller nations, gained undying merit for the salvation of the Slovak nation and the Czech spirit in national life and literature; May 1, as the symbol of social progress that we desire in our democratic nation; and finally October 28, which already on October 14, 1919, by Law no. $555 \mathrm{Sb}$., was declared a state holiday as the great day of our liberation, on which the centuries - long struggle for the renewal of our long-ago independence was completed. So that the historical national significance of this day is not disturbed by anything, not only are the regulations for holiday rest in schools and offices which apply to other Republic memorial days valid, but all regulations for Sunday rest and its dignified external celebration also apply to this day and are secured by effective measures. ${ }^{18}$

It also pointed out that the 1919 law did not precisely define whether a state holiday is a day of rest from work (as, in Old Czech, "nedělí, the Lord's Day). And since the republic had to build its own legal order, which also included the unity (unification) of all former Hungarian and Austrian legal regulations, (the post of Minister for Commonality of Laws and Administration Organizations existed until Dec 1, 1938), the Justification Report also pointed out the administrative, economic and transportation "fatal results" which the overall legal disunity was bringing. In this context it also literally states that "the issue of which days are holidays and which days of rest had not been settled and unified for the whole territory of the Republic."

${ }^{17}$ For wording of the Law, see http: / / www.epravo.cz/vyhledavani-aspi/?Id=3865\&Section=1\&IdPara=1\&ParaC=2 ${ }^{18} \mathrm{http}: / /$ www.psp.cz/eknih/1920ns/ps/tisky/t5061_00.htm 
This legislation remained in force until the occupation of the Republic in 1939 even though October 28 was not celebrated in 1938.

\section{OCTOBER 28, 1918 S AND THEIR TIME SPACE}

The plural used in the title of this section points to the fact that the constitution of the new Republic was a long-lasting and conflicting process reflecting the complex national situation in Central Europe as well as the revolutionary nature of the period following the end of the Great War. ${ }^{19}$ There was actually a number of October $28 \mathrm{~s}-$ six in $\mathrm{all}^{20}$ if we discount the "Bolshevik" October 28. First of all the Slovak Republican Council in spring 1919, then the call for a general strike in December 1920 declared by the fledgling Communist left, contained under the general heading "the struggle for the character of the Republic", which was meant to be a sort of 'response' to the Bolshevik October revolution in Russia. ${ }^{21}$ Moreover it is not strictly possible to link them only with the political efforts of these individual nations and nationalities which brought them about. For one thing they were not always "fully national"; in each such October 28 there were people of other opinions (e.g. pro-Austrian, pro-Hungarian, pro-Czechoslovak). These national attempts were always integrally and reciprocally tied to each other, and the time order of their activities and public demonstrations was not united either, with respect to October 28 as the date of the formation of the Czechoslovak Republic. Each of them had its own time-space, the set of events and dynamic of their own, but nonetheless they culminated in one official October 28, which by itself, however, is not completely understandable without the framework time-space of the end of the Great War and "Finis Austriae". This time space is wider and does not always directly relate to internal Czech/Czechoslovak happenings in the years 1918-1920. Still, its events with their dynamic were decisive for it. Setting the milestones of this time-space is not simple because its boundaries reach back to before 1918 and far forwards to the present day. Moreover, these events and their accompanying signs fill a political legitimization function and so are open to manipulation according to need. Despite this, it is nonetheless possible to name some that both played a functional legitimatizing role and are at the same time significant historical milestones: Great Morava in 1018, the annexation of Croatia to the Crown of St. Ste-

${ }^{19}$ Collectively, see 1918 - model komplexního transformačního procesu?, ed. by L.Kostrbová, J. Malínská et al. Prague 2010.

${ }^{20}$ Cf. the slogan from the 1950s, "Without the USSR, the CSR would not exist!"

${ }^{21}$ Referring here to the wise analysis of Zdeňek Kárník. See Z. Kárník, České země v ére První republiky I, Prague 2000, and Z. Kárník, Malé dějiny Czechoslovak, p. 34-88. 
phen; 1526, to which the emergence of the Habsburg Central European dynasty can be attributed; the Czech War of 1618-1620; the revolutionary year of 1848 and its Central European national emancipation demands; the duality of the monarchy in 1867. Naturally, ranked among the consequences of the events of 1918 are the years 1938 and 1939, the inevitable results of the ending of WWII in 1945 (more specifically, 1944-1945), the Soviet domination of Central and Southern Europe in the second half of the 1940s, and of course the fall of the Communist regimes in 1989-1991 and the consequences which have led right up to the present.

Among the listed October 28s, the Czech one that takes the first place: simply because it was politically the most powerful ${ }^{22}$, could call on its own state tradition, and in the European and American consciousness the Czechs were better known that the Slovaks, the other party in the CSR. It should be mentioned however that the label "Czechs" often covered the Slovaks too. The Czech-Slovak problem (or the 'Slovak issue') was also one of the decisive factors throughout the entire history of Czechoslovakia.

Its sister October 28 was Slovak. It can rightly be claimed that October 28, 1918 was the day when the "modern Slovakia" was born ${ }^{23}$. United in the general consciousness, both Czech and Slovak, is October 30's Martin Declaration, when in Turčiansky Svätý Martin a gathering of 200 representatives of the Slovak nation proclaimed itself in favour of Czechoslovakia and also elected their supreme national body, the Slovak National Council. The Martin Declaration declared Slovaks as part of the "CzechSlovak nation" and, in the spirit of the recognized right to self-determination, chose the common Czechoslovak state. The Slovak domestic decision had of course its prehistory, in fact like a long one, beginning in the second half of the 18th century ${ }^{24}$. Near the end of the 19th century, a group concentrated around the magazine Hlas voted in support of the idea of Czechoslovak unity and later gained the support of other periodicals struggling for the activation of Slovak political life ${ }^{25}$. In the Pittsburgh Declaration of May 30, 1918, Slovaks living in the USA supported a common state, though with a promise of autonomy.

However, the overall political, social and cultural situation in Slovakia was more complex than the activity of the Slovak National Council would indicate. The strong and progressively omnipresent Magyarization, strengthened by the division of the

${ }^{22}$ See Z. Kárník, České zemè I, p. 48.

${ }^{23}$ D. Kováč, "Štátne sviatky", in: Pamět' míst, událostí..., p. 113-114.

${ }^{24}$ See Slovanství v národním životě Čechů a Slováků. Prague 1968.

${ }^{25}$ The Hlas magazine was published 1898-1904, and its main contributors indluded V. Šrobár (first CS Minister for Slovakia) and the Slovak agrarian P. Blaho. The publisher of Slovakia Weekly (from 1903) and M. Hodža, 1935-1938 Chairman of the CS Government, were also close to it in the conception of the Czech-Slovak relations. 
monarchy in 1867, naturally improved the relations with the Czech nation, but only with a part of the intelligentsia, particularly in West and Central Slovakia. The Magyarization pressure, in fact, forced many towards Hungarian allegiance (the period terminology spoke of "Slovak Hungarians"). So, for Slovakia the Hungarian issue was much more difficult than was the German issue for the Czechs ${ }^{26}$. The nationality situation in Slovakia was compounded by its German minority (Carpathian Germans). The Slovak October 28, therefore, cannot be separated from the Hungarian one, and could only be said to be brought to an end by the military occupation of Slovakia after the defeat of the Hungarian Red Army and the Slovak Republic Council in June $1919^{27}$, and the signing of a peace treaty with Hungary at Trianon on 4 June 1920.

The Hungarian October 28 is chiefly connected with the signing of the Trianon Treaty of June 4, 1920. Upper Hungary lost two-thirds of its historical territory, which could do no other than to leave deep scars on the Hungarian national and historical consciousness; this scar was the "Trianon trauma". The password to this memory became "No-No-never!" (Hun. Ném-Ném-Soha!), "thrice no, Tria-non"28. This October 28 too began at the end of October, 1918, specifically October 30-31, when the Hungarian National Council was first formed, with a coalition government created on the following day. The goal of the new government was to retain the territorial integrity of Upper Hungary. This, in light of the heretofore national policy of the Budapest government and the war-strengthened nationalist demands, and due to the de-facto post-war situation of power, was doomed to failure. The newly-formed Czechoslovakia took in a significant part of the Hungarian "Upper Lands" which, just as the Czech lands for Austria, in many ways was the economic basis of the Hungarian monarchy. Bratislava was even the Coronation site of Hungarian kings from 1563 to 1830. Accordingly, the loss of this territory was especially sensitive. As with the case of Poland, the new delineation of the state border played a crucial role. The southern Slovak border had no historical precedent and the mix of Slovaks and Hungarians on the Slovak territory did not allow (as was the case of the Cieszyn region or the ethnic borders between Czechs and Germans on the Czech land) for drawing up the border on ethnic principles. So, the principle remained purely geographic, and the flow of

${ }^{26}$ See the preface by R. Chmel to the anthology Slovenská otázka v 20. storočí. Bratislava 1997

${ }^{27}$ L. Lipták, Slovensko v dvadciatom storočí. Bratislava, 2011 (first published in 1968!), p. 78-79

${ }^{28}$ P. Biháry, "Images of Defeat: Hungary after the Lost War, the Revolutions and the Peace Treaty of Trianon", in: Crossroads of European histories. Multiple outlooks on five key moments in the history of Europe. Strasbourg 2006, p. 165-172; É. Kovács, “O traumatickej pamäti Trianonu”, in: M. Michela, L. Vörös et al., Rozpad Uhorska a Trianonská zmluva, K politikám pamäti na Slovensku a v Mad'arsku. Bratislava, 2013, p. 265-276; A. Pók, "Ungarische Interpretation der Gründung der Tschechoslowakei”, in: 1918 - model komplexního transformačního procesu?, ed. by L.Kostrbová, J. Malínská et al., p. 29-38. 
the Danube river and the connecting Ipel' river was a natural suggestion. In the end the main stream of the Danube was chosen, which increased the Hungarian minority in Czechoslovakia to 762000 persons. The Hungarian irredentists, symbolically emphasized by the two attempts by Karol I Hambursky at the restitution of royal power, brought about a sharp reaction from the Czechoslovak party, as did the entry into the conflict of the Hungarian National Council, also aiming for a retention of the territorial integrity of Upper Hungary albeit in the shadow of the Red Flag of the Russian Bolshevik Revolution.

The fourth October 28 was German. It started on the same day, when four self-governing territories, which immediately united in Deutschböhmen, declared themselves part of German Austria. Hidden behind this step was a naïve calculation that Austria would unite with Germany, and the Czech Germans would thus become German citizens. This de facto strengthening of the defeated Germany was as unthinkable for the Allies, as the separation of their border territories was unimaginable for the Czechs. It was also an infringement of the old Czech state law which had shaped Czech politics in the Empire Council since 1879 as well as the laws of the old Czech state that existed since the last third of the 9th century (it was legally cancelled by a declaration of the CSR National Constitutional Assembly on November 14, 1918). Moreover, the separation of the border territories, in light of the geographical character of Czech and Moravian lands, would harm the economic and transportation infrastructures built up over centuries by both countries; the formation of the Sudetenland province after the Munich Agreement of 1938 only confirmed this fact ${ }^{29}$. The declaration was a reaction to the October 21 proclamation of German Austria, which also preceded the Czech October 28. The existence of the 'German Czechs' was of short duration - with the blessing of the Allied powers, the newly-formed Czechoslovak army and the national physical education organization Sokol ${ }^{30}$ occupied the territory until Christmas 1918.

This, however, was not the end of the German October 28. The decisive moment for the 'German' interpretation of this date was March 4, 1919', later dubbed the Day of Sudeten -German Self-determination, or Remembrance. On this day the new Austrian parliament, elected on February 16, 1919, met in Vienna. Germans living

${ }^{29}$ Kárník, Malé dějiny, p. 46- 53. The Nazi leaders were aware of this: K. Henlein, standing at the head of the Imperial County Sudetenland in 1943 complained to M. Borman of the onerous border counties that cause transport and economic problems and demanded the modification of their borders at the expense of the Protectorate. See S. Kokoška, "Rok 1943 v Protektorátu Čechy a Morava”, in: Válečný rok 1943 v okupované Evropě a v Protektorátu Čechy a Morava. Prague 2014, p. 58

${ }^{30}$ See M. Waic, Tèlesná výchova a sport v politickém životě meziválečného Československa, in print.

${ }^{31}$ See: Státní politika vưči německé menšině v období konsolidace politické moci v Československu v letech 1918-1920. Edice pramenů, ed. by J. Harna, J. Šebek, Prague 2002; E. Hahnová, Sudetonèmecká vzpomínání a zapomínání. Prague 2002. 
in Czech counties were allotted 85 seats, but the Czechoslovak government banned voting on its territory: it really had no alternative. In response, the Czech German political representatives declared a general strike on the day of the first session. The events of this fateful day turned bloody. 58 demonstrators were shot dead, about 134 were injured, and on the Czech side 5 died and 4 were wounded ${ }^{32}$. Even those historians ${ }^{33}$ who made a thorough search for documentation immediately after the March 4 events, particularly in Kadann where 24 died, were unsuccessful in getting a precise account of the events. The end of the German October 28 could be dated on September 10, 1919, when a peace treaty was signed with Austria at Saint Germainen-Laye. This marked the factual, internationally legal confirmation of the existence of the CSR; the Treaty of Versailles with Germany added the Hlučín region to the CSR, which became part of the Republic on February 4, 1920.

The beginning of the fifth October 28 - the Polish one - can be set to October 19, when the Polish National Council of Cieszyn Silesia was assembled (its Czech form, the National Committee for Sliezsko, appeared on October 29). Its time-space can be said to end on July 28, 1920, when the final Czechoslovak-Polish border line was established by a decision of the Council of Allied Ambassadors. Developments in this interval were as dramatic as the development of the Hungarian-Czechoslovak dispute. The Silesian-Polish side militarily occupied the area on the night of October 30-31, but on November 1 the Silesian National Committee declared it a part of the CSR. The reasons of the conflict were not only historical (from 1339 this territory was part of the Czech crown) or national (according to the 1921 census, about 104,000 of the population claimed Polish nationality, with a total of about 110,000 living in the CSR), but clearly economic as well. The territory was a significant coal basin, with heavy industry concentration and the important Košice-Bohumín railway line, forming, along with the Břeclav-Bratislava route, the only rail link between the Czech and Slovak lands. On November 5, an agreement came into being between the national representatives of both sides on the formation of a demarcation line. However, it came immediately under fire, mainly because the Košice-Bohumín railway route ran on Polish territory. Further development was catalysed, just like in the case of the CzechGerman dispute, by the elections to the Polish parliament. These were set for January 26, 1919, but on January 23 the Czechoslovak military crossed not only the Cieszyn demarcation line but also the border in the Spiš and Orava regions, another territory which the CSR and Poland were disputing. The result was the so-called Seven Days

${ }^{32}$ Numbers according to the report of the Presidium of the CSR Ministry of the Interior. See State Policy, doc. 61 , p. $85-87$

${ }^{33}$ J. Škrábek, Včerejší strach, Prague 2002, p. 32-38. 
War, which was ended by pressure from the Council of Allied Ambassadors and by the establishment of a new demarcation line, which was ratified by the CzechoslovakiaPoland Treaty of February 3, 1919. The contested territory was provisionally placed under international control ${ }^{34}$.

Finally, the sixth and last October 28 was the Rusinian one (Subcarpathian Rus). Its has the shortest, even if the most complex history from a number of standpoints. Subcarpathian Rus (today the Zakarpattiá area of Ukraine) was a "white space" that was "left behind" by the powers after the collapse of Austro-Hungary. Here there was a conflict of interest among the Poles, the Ukrainians, the Russians, and the strongest of them, the Hungarians. Magyarization was even stronger and more influential here than in Slovakia. It was a nationally very mixed territory, it did not even have a common Rusinian language. Immediately three Rusinian National Councils were formed and then united in the Central Rusinian Council which, by the Uzhhorod Memorandum of May 8, 1919, elected to join the CSR, although on the condition of autonomy. The Memorandum was also sent to the Versailles Conference which, along with the Czech government and president, expressed its consent. Motivating this decision was the Rusinians' unwillingness to remain part of Upper Hungary, added to their fear of Bolshevism. Similarly to the Slovak Martin Declaration, this document was subject to the decision of Rusinians living abroad. On November 18, 1918 the National Council of Upper Hungarian Rusinians (Ukrainian) in Pittsburgh agreed with the step. The overall result was that the national, social and cultural situation on this territory was even more complicated than in Slovakia.

This more or less factual overview of the six "October $28 \mathrm{~s}$ " with both their internal differences and correspondences shows the constellations of the period and the complexity of forming a new state which needed to find its unifying idea. It was a concept of a democratic republic which would guarantee to all its citizens, regardless of nationality or religion, equal individual civil rights granted by the Constitution of 1920. But this attempt at Czechoslovakism ran against the collective identity of the individual nationalities - including the Czechs - living in the republic, their mental stereotypes, their prejudices against the others, and their related political self-images and demands. Fulfilling them all and for everyone was not possible at that time; the republic had essentially only ten years of peaceful development between the settling of the post-war crisis and the world-wide economic crisis, which impacted the Czechoslovak economic and political life. This inability was expressed most clearly in the demands for political autonomy: meeting one would in the end mean meeting

${ }^{34}$ D. Gawrecki et al., Dějiny Českého Slezska 1740-2000 I. Opava, 2003; Zarys dziejów Śląska Cieszyńskiego. Ostrava-Prague 1992. 
them all; yet only three of the October 28 s were acceptable, while the remaining three (Polish, Hungarian, and German) would only serve to split up the country. Accordingly, the republic sought, besides the civil law principle, other symbolic, potentially unifying lines. It is no surprise that these were for the most part historically legitimizing. Among these should be mentioned the 1929 celebrations of the supposed St. Lawrence millennium ${ }^{35}$, the 10th anniversary of the founding of the CSR, and the already mentioned celebrations of the birthday of T.G. Masaryk.

\section{RITUALS OF OCTOBER 28}

Invariably linked with holidays are rituals, which are the visible manifestation of their memory ${ }^{36}$. October 28 was not just an official state holiday but, initially for the Czechs and later not only for them, an intimately experienced holiday. A dominant role in its perception was played, understandably, by the Czech October 28, since it was the decisive and the strongest one ${ }^{37}$. Aa law from 1919 declared it an official site of memory, and therefore its annual celebration was a political manifestation. The holiday was celebrated in practically every municipality, and not just by representatives of the national and local administration, teachers, their pupils and students, but also by those who were 'foot-soldiers' in the fight for independence: members of the Czechoslovak legions and Russian, French and Italian volunteer units made up of prisoners of war, and finally Czechs and Slovaks living in Allied countries. Without them, none of the celebrations of this holiday would have occurred.

The law ensured that these celebrations would indeed have the support of schools. They organized their own academies, where instruction booklets containing suitable texts for declarations were distributed. These were mainly texts from the so-called legionnaire literature, mostly by two writers who had achieved the rank of general, Rudolf Medek and Frantisek Langer. Medek's extensive pentalogy, the Legionnaire's Epic (1921-1927) describes the fate of Russian legionnaires after they returned from Russia. Its concluding part, Anabasis, narrating battles with the Bolsheviks and the journeys of the legions along the Trans-Siberian highway to Vladivostok, was awarded the State Award for Literature in 1928. Apart from breaks caused by political circumstances, from 1920 this prize was awarded annually, always on October 28.

${ }^{35}$ P. Placák, Češi, Němci a Slováci v roce 1929. Prague 2002.

${ }^{36}$ See E. Manová, "Slávenie trascendentna alebo oslavovanie moci? Sviatkovanie, slávnosti a oslavy očami historikov, in: I. Kušniráková et al, "We will go out at night in a torchlight parade and we will light up the world". Bratislava 2012, p. 9-18.

37 Kárník, Malé dějiny, p. 87; idem, České země I, p. 48. 
A whole series of other activities and works of various ranks and levels had an educational character. The birth date of the CSR entered into a children's story by Josef Čapek, How the Dog and Cat Celebrated October 28. Its content is simple: both of the characters want to celebrate this day in dignity and so go into debt to be able to afford a national flag. From today's standpoint this would strike us as hard-to-swallow political agitation, but the connotations of the times, especially when the Nazis ${ }^{38}$ threatened the republic, must not be forgotten.

Of course the holiday was also centred on personalities. The 'Men of October 28 ' entered into history. These were members of the Czech National Committee who were in Prague on that date and led and carried out the overthrow. They included future Czechoslovak politicians, in particular the Triumvirate of T.G. Masaryk ${ }^{39}$, Edvard Beneš, and Milan Rastislav Štefánik ${ }^{40}$, the creators of the Czechoslovak National Council and later members of the exiled Czechoslovak Provisional Government. The October 28 ritual led directly to the creation of its historical memory or memories.

\section{MEMORIES OF OCTOBER 28}

October 28, 1938 was to be the ceremonial public opening date of the Liberation Memorial on the Prague hill, Vitkov ${ }^{41}$. On this peak on July 14, 1420 the victorious battle between the Hussites and the First Crusade Expedition took place. On its anniversary (1420), a memorial was to be erected to the victor of this battle, Ján Žižka of Trocnova. After 1918 this idea was transformed into constructing a memorial of the first uprising, in essence a necropolis of the new democratic state (according to the original plans T.G. Masaryk too was to be buried there but he refused; on September 7, 1948, a part of the funeral of E. Beneš was held there). For the 1938 occasion a large military parade was to take place, but one month after Munich and the handover of the Czech borderline to the Nazi Germany, it was queer to celebrate the twentieth anniversary of the Republic. So the celebrations were cancelled, and the work on

${ }^{38}$ See http://www.csfd.cz/film/224593-jak-pejsek-s-kocickou-slavili-28-rijen/ (accessed: June 9, 2015); http://www.rozhlas.cz/archiv/rozhlasovyrok/_zprava/jak-pejsek-s-kocickou-slavili-28-rijen--1274854 (accessed: June 9, 2015). 3 min. of the text are also shown in German. "Pohádka se dočkala i svých prolongací, např. Kočička a pejsek za protektorátu či jejich nová př́běhy.” See http://novepribehy.webnode.cz/album/rijen-oktober/p1060237-jpg/.

${ }^{39}$ Masaryk played an integrationist role in Czechoslovak nationality issues. This applied to Slovakia, See Z. Hajachová, “Oslavy narodenín prezidenta T. G. Masaryka na Slovensku”, in: Kušniráková et al., Vyjdeme v noci, p. 171-185, but also to Czechoslovak Germans; we recall his distaste for the occupation of Prague's German Estates Theatre by the actors of the Czech National Theatre in 1920. (See J. Hilmera, Stavovské národu!. Prague 1991, p. 37-42).

${ }^{40}$ M. R. Štefánik was commemorated by a burial mound at Bradlo in his native town, Košaríska, completed in 1928 , rather than a monument.

${ }^{41}$ Commander of the Liberation Monuments, which was a military institution, was General Rudolf Medek 
the unfinished memorial site continued even after the occupation by Germany on March 15, 1939 ${ }^{42}$. Under the Protectorate the official recognition of October 28 as a state holiday was banned ${ }^{43}$. But removing the Memorial, one of Prague's dominant sites, would be no easy task, so it became the property of the Third Reich with the intention of returning it to its original function as a mausoleum and a memorial of one-thousand years of Czech (i.e., Czech-German, not national) military history. In the end it was demolished in the conditions of 'total war', although a whole range of valuable works of art was saved by the Czech uprising ${ }^{44}$.

Thus in 1939-1944, October 28 became a normal working day, replaced by a new 'holiday' on March 15, the day of integration of the Czech counties into the German Empire ${ }^{45}$. This attempt was unsuccessful of course; erasing it from the nation's memory, or even from the public space, was impossible. The October 28, 1939 demonstrations in Prague became the catalyst for a series of events that culminated in the closing of Czech universities on November 17, 1939. The repression of the holiday played October 28 into the hands of the Prague resistance ${ }^{46}$, who sought out a publicly celebrated feast to act as a cover for the holiday. Since in the religious calendar it was the feast of St. Jude Tadeáš, on October 28 candles and flowers began to be placed by his statue at the monastery at the Republic Square in Prague New Town. We should mention that this saint is the patron of lost causes.

Needless to say, the October 28 holiday was immediately reinstated in 1945 by the Republic Presidential Constitutional Decree 11/1944 on Renewal of Work Order, and by the Provisional National Assembly on 19.12.1945 ${ }^{47}$. It was also connected to the preservation and over-layering of its memory ${ }^{48}$. On that day the CSR Provisional National Assembly began its activities by ratifying Edvard Beneš in the post of President of the Republic. Four days prior, effective October 27, 1945, Beneš signed the so-called Nationalization Decrees, by which heavy industry, smelting, mining,

\footnotetext{
${ }^{42}$ See J. Galandauer, Chrám bez boha nad Prahou. Památník na Vitkově. Prague 2014, p. 62-65.

${ }^{43}$ See Government Proclamations since September 18, 1939, http://www.epravo.cz/vyhledavani-aspi/?Id= 8084\&Section=1\&IdPara $=1 \&$ ParaC=2 (accessed: May 26, 2015).

${ }^{44}$ J. Galandauer, Chrám bez boha nad Prahou. Památník na Vitkově. Prague 2014,p. 90-98.

${ }^{45}$ Of course in the Slovak Republic at that time, March 14 was celebrated as the day of the foundation of the independent Slovak state. See I. Kamenec, "Oslavy vzniku samostatnej Sklovenskej republiky v rokoch 1940-1945”, in: Kušniráková et al., "Vyjdeme v noci”, p. 208-224

${ }^{46}$ D. Hájková, “28. ř́ijen a jeho podoby”, in: 1918 - model komplexního transformačního procesu?, ed. by L.Kostrbová, J. Malínská et al., p. 225-227.

47 By this decree the CSR legal regulations valid until Sep 29, 1938 were returned to force. See http://www zakonyprolidi.cz/cs/1945-30 (accessed: May 26, 2015). The new holiday code was set by Law no. 248/1946 Sb., where October 28 remained the only state holiday. See http://www.psp.cz/sqw/sbirka.sqw? cz=248\&r=1946 (accessed: May 26, 2015)

${ }^{48}$ Only contextually would we add that a law was passed in 1946 establishing March 7 the day of birth of T. G. Masaryk, the President of Independence. The law was valid until 1951
} 
banking, and insurance firms with more than 500 employees (in certain cases, more than 150) were nationalized. These activities fall into the October 28 time space as a continuation of the 'socialization' of the economy and the overall 'national cleansing': the evacuation of the German population was officially ended on October 28 1946 (even though, in fact, it continued to 1947) ${ }^{49}$. The new content of this holiday ${ }^{50}$ was actually codified by Law no. 93/1951 Coll. on State Holidays, Days of Rest and Memorial and Significant Days ${ }^{51}$. By this legislation October 28 ceased to be a state holiday (from then on, the only state holiday was May 9, the Day of Liberation of the CSR by the Soviet Army) and became only a memorial day, the Nationalization Day ${ }^{52}$. This attempt to give a new meaning to October 28 was formulated quite unequivocally by the Justification Report on Law 93/1951:

Leaving October 28 as a day of rest and its designation as Nationalization Day are justified by the fact that in October 1945, in the first year after liberation, the people took into their own hands by nationalization the most significant parts of the national economy, and precisely on October 28 the nationalization of a general part of industry and all banking was manifestly proclaimed. By this act, made possible by the historical victory of the Soviet Union in the Second World War and by the liberation of our homeland by the Soviet Army, was asserted the true will of the people as shown in struggles lasting whole decades. October 28, 1945 fulfilled the desire of the people and brought about what was taken from the people by the bourgeoisie after October 28, 1918; in the Czechoslovak Republic the people became the rulers in their own homeland and by the nationalization took the first step towards socialism. After the liberation, October 28 became a day of celebration of nationalization and also the anniversary day of the ceremonial declaration of the two-year and five-year economic plans ${ }^{53}$.

Along with the flaming ideological nature of this justification, historical legitimization is also supported here: in the post-war Czechoslovakia, the objective historical development leading towards the victory of socialism goes on. May 9 is the 'second liberation', in opposition to the first, carrying within itself also a social content ${ }^{54}$. The justification report therefore also speaks literally of the 'new conception' of this

49 Z. Beneš, V. Kural et al., Rozumět dějinám. Prague 2002, p. 214-215.

${ }^{50}$ For the fate of public holidays and memorial and significant days of Czechoslovakia after World War II in detail, see J. Socha, “Proměna př́běhu aneb státní svátky, významné a památné dny v letech 1946-1990” in: Historie - Otázky-problémy 4, 1/2012, p. 55-72.

${ }^{51}$ http://www.psp.cz/eknih/1948ns/tisky/t0587_00.htm (Accessed: May 26, 2015)

${ }^{52}$ D. Hájková, “28. ř́ijen a jeho..., ", p. 227-230.

${ }^{53}$ See http://www.psp.cz/sqw/sbirka.sqw?cz=93\&r=1951 (accessed: May 26, 2015).

${ }^{54}$ This concept found its expression in the completion of National Monument in Vítkov, Prague. In the first half of the 1940s the original building was added to the Hall of the Soviet Army (opened in 1955). See J. Galandauer, Chrám bez boha nad Prahou. Památník na Vitkovè. Prague, 2014. 
holiday. Its significance is however reduced; not only because it was not declared a state holiday, only a memorial day, but also due to the fact that it was a 'moveable feast'. The law allowed, for economic (!) reasons, a day of rest falling on October 28 to be shifted to another day (usually a Saturday or a Monday). This created a two-day break from work, the first day of which was taken up by official celebrations and the second then became a day of 'rest for the workers'.

The Nationalization Day never really caught on as a true holiday. It is impossible to force a memory - and so it occasionally happened, particularly in the 50s, that flowers were secretly placed at the memorial to the first uprising. These were perhaps intended primarily as memorials to the men who had died at the front, probably by family members. But together with, and inseparable from, this were (unwelcome) memorials to the First Czechoslovak Republic. Certain changes brought about a relaxation of political relations in the Czechoslovakia of the 1960s. For three clear reasons, October 28 took on a special meaning in 1968. For one, that year marked the 50th anniversary of the formation of the Republic. Moreover the law on a federal state, intended as a solution to the unsatisfying national legal situation of Slovakia, was adopted on this date. But above all, these two events gained a new current dimension by the occupation of the CSSR on August 21, 1968 by the forces of the Warsaw Pact. The fully justified fears of civil acts on the anniversary of the Republic, which were bound to be anti-Soviet, led to extensive measures on the part of the Czechoslovak security units ${ }^{55}$. These fears sprang mostly from the activities of students. Still and all, it was inconceivable to ignore the anniversary, so its only official recognition was a ceremonial joint session of the supreme political bodies at the Prague Castle and an evening presentation of Smetana's opera, Libuse, at the National Opera. On the previous day, wreaths had been laid at the Tomb of the Unknown Soldier at Vitkov by K. Gottwald and A. Zapotocky, the tombs of Soviet and other foreign soldiers at Olsanske cemeteries, and the fighters at the Prague barricades. There was no official mention of T.G. Masaryk or E. Beneš ${ }^{r 5}$. The logic of these celebrations was therefore fully in accordance with the intentions of the Law on State Holidays from 1951; the commemoration of the role of the Soviet army was meant to enshroud the foundation in 1945 of the liberated state itself.

${ }^{55}$ Documentation See http://www.abscr.cz/cs/vystava-k-vyroci-republiky (accessed: May 26, 2015)

${ }^{56}$ It was however commemorated 'semi-officially': A National Front delegation, led by the head of its Central Committee Evžen Erban placed a wreath on the tomb of T. G. Masaryk. On October 27 a Central Committee delegation led by its head Evžen Erban flew to Sezimovo Ústí and placed a wreath on the tomb of Edvard Beneš. See P. Zídek, Hana Benešová. Prague 2014, p. 229. 
The setting of the state holidays from 1951 remained valid for 24 years. Under the Law 56/1975 of June $11^{57}$, October 28 ceased to be even a day of rest, despite the fact that it was included in the law on Czechoslovak federacy adopted on October 28, 1968 , essentially a legal reform of the state. In 1988, clearly in relation to the so-called 'restructuring', October 28 was reinstated as a state holiday, with the formation of the state mentioned in new publications issued that year. It is indicative that this new reform was approved in September and, presumably due to time constraints, only by legislative measures and not as a law ${ }^{58}$. Also reflective of the period were the fears on the part of the political powers regarding its celebration. An official demonstration was called for October 27 at Prague's Wenceslas Square, but civic groups (labelled as the 'internal enemy') called for an independent demonstration at the same place for October 28. The state security bodies feared similar demonstrations in other towns throughout the Republic, including the planned laying of a wreath at Masaryk's tomb in Lanov. Of significance is the fact that roughly half of the participants of the Prague demonstration were citizens with no ties to the civic initiatives, which was a sign of the growing civic disobedience; the secret police ( $\breve{S t B})$ drew specific attention to this fact $^{59}$. Of course, a similar situation occurred in the following year, and the memories of October 28 directly preceded November $17^{60}$.

November 1989 brought about significant changes: Law no. 167/1990 Coll. of May 9, 1990 designated October 28 as a state holiday again, as the Day of the Establishment of the Independent Czechoslovak State, which name remained in place in the 2000, 2004 and 2006 updates. After the splitting of Czechoslovakia, however, it remained a state holiday only in the Czech Republic. Still, its memory remains alive in Slovakia, with a monument to M.R. Štefánik and T.G. Masaryk in Bratislava, and also in the Subcarpathian Rus area of Ukraine. After the downfall of the Soviet Union, the idea of re-joining Czechoslovakia had a strong backing there. After their historical experience with the USSR, this should come as no surprise. In fact, it was still possible after decades to see the Czechoslovak state emblem on some of the most distinguished buildings in the centre of the region's towns. Memories of the Czechoslovak state administration, particularly in education and health care, still remained very alive and did not disappear even after the inevitable frustration of the region's accession dreams ${ }^{61}$.

\footnotetext{
${ }^{57}$ Source: http://www.abscr.cz/cs/vystava-k-vyroci-republiky (accessed: May 26, 2015).

${ }^{58} \mathrm{http}: / /$ www.psp.cz/sqw/sbirka.sqw?cz=56\&r=1975 (accessed: May 26, 2015)

${ }^{59}$ See http://www.abscr.cz/cs/vystava-k-vyroci-republiky (accessed: May 26, 2015)

${ }^{60}$ P. Pithart, Devétaosmdesátý. Vzpomínky a přemýšlení: krédo. Prague 2009

${ }^{61}$ E.g., the Krajanský Klub of T. G. Masaryk still exists (http://www.klubtgm.cz/aktualne.ph), as well as J. A. Komenský Society of Czech Culture in Uzhhorod, the Uzhhorod Association of Slovaks (http://uzhss.webnode.cz/), Slovak Motherland in Transcarpathia, M. R. Štefánik Slovak Community, and others
} 


\section{CZECH OCTOBER 28 TODAY}

The history of the Czechoslovak October 28 is a combination of the Czech/Czechoslovak history of the 20th century as well as of the history of Central Europe, without which it cannot be fully understood. As we have seen, this date is the bearer of a multiple memory, and thus a bearer of memories ${ }^{62}$. Its pluralized time and content heterogeneity truly creates identifications and legitimizations, messages and approaches. There were not only 'positive' memories but also 'bad' memories (M. Kuly's term). The Czech state idea and Czechoslovak state idea, the national and the historical consciousness of the Czechs and the Slovaks, as well as those of all the other nations living in the CSR are integrally overlapped in the memories of October 28. The collective and individual social experience of their peoples is also projected onto them, including the features of cultural identity of those who were its original participants. But perhaps it also projects to those with only a remote experience of the holiday gained through hearsay over generations. October 28 and its timeframe bear memory features similar to, e.g., the German November 9, the Polish set of holidays on May 1 and $3^{63}$, and the Slovak conjunction of state holidays on August 29 and September 1. Despite all their specific differences, these calendar memory sites have in common their own 'filtered memories' (M. Kuly's term) leading to a modification of the meaning of the memory sites and to a replacement of their original meaning, for example through the idea of its 'completion' as witnessed in the fate of October 28 from 1951 to 1989 in Czechoslovakia. The most emphatic feature of the filtration of memory is in the actual liquidation of the memory of a given site for reasons which are always purely ideological, always 'forced, and which fly in the face of the living history and collective memory. The self-willed extinguishment of the meaning of a memory site which follows the dynamic of historical evolution is of course an entirely different case ${ }^{64}$. The memory of October 28 is in fact the meeting-place of all such feature changes; today it is nostalgically and politically commemorated at official places. Commemorative gatherings are held in the National Museum Pantheon, wreaths are placed on the tombs of Masaryk and Beneš. October 28 has become an 'ordinary day' on which state awards and prizes for literature are distributed. It is almost uncelebrated in the street, although a majority of Czechs agree that commemorating state holidays is important $t^{65}$ and they perceive October 28 as the most significant of these $\mathrm{e}^{66}$.

${ }^{62}$ See M. Kula, Nośniki pamięci historycznej. Warsaw, 2002.

${ }^{63}$ M. Kula, Nośniki pamięci historycznej. Warsaw, 2002.p. 107-108

${ }^{64}$ M. Kula, Nośniki pamięci historycznej. Warsaw, 2002. p. 90-99.

${ }^{65}$ According to Actor Research from 12/2009, 78\% of those questioned considered its memory as definitely or rather important. J. Šubrt - J. Vinopal et al., Historické vědomí obyvatel České republiky perspektivou sociologického výzkumu. Prague 2013, p. 183.

${ }^{66}$ Parliamentary documents: Among the state holidays for the people, the most significant is the celebration of October 28. Nov 18, 2013 11:14 (accessed: Oct 16, 2014). 
The rewriting of the memory of October 28 in the Czech 20th century history had failed. Erasing it from the historical memory or pushing it into the private sphere has to a significant extent succeeded, as with other holidays. Even the Day of the Establishment of the Independent Czechoslovak State has come to be perceived as just a day off work and therefore a day for relaxing and for private life ${ }^{67}$. Not only political turnabouts are to blame, principally the dissolution of the common Czech and Slovak state but also the change of ideals, a shifting of values and attempts to rewrite historical memory called forth by a loss of the reason for observing the holiday ${ }^{68}$.

TRANSLATION: EVA SCIRANKOVÁ

${ }^{67}$ J. Šubrt, J. Vinopal et al., Historické védomí obyvatel České republiky perspektivou sociologického výzkumu. Prague 2013, p. 182.

${ }^{68}$ I thank my colleagues M. Michel of FF UK in Prague and M. Bubna of KTF UK in Prague for their valuable comments.

\section{BIBLIOGRAPHY:}

Assmann A., Erinnerungsräume. Formen und Wandlungen des kulturellen Gedächtnisses, München 1999

Beneš Z., Kural V. et al., Rozumět dějinám, Prague 2002

Biháry P., Images of Defeat: Hungary after the Lost War, the Revolutions and the Peace Treaty of Trianon, in: Crossroads of European histories. Multiple outlooks on five key moments in the history of Europe, Strasbourg 2006, pp. 165-172

Boisserie E., Quelques réflections sur les querelles d'interpretation de la Déclaration du Martin du 30. octobre 1918, in: Pamět mist, událostí a osobností: historie jako identita a manipulace, M. Hlavačka, A. Marés, M. Pokorná et al., Prague 2011, pp. 71-82.

Domańska E., Pamięć, etyka i historia, Poznań 2000

Galandauer J., Chrám bez boha nad Prahou. Památník na Vitkově, Prague 2014

Gawrecki D. et al., Déjiny Českého Slezska 1740-2000 I., Opava 2003

Gawrecki D. et al., Zarys dziejów Śląska Cieszyńskiego, Ostrava-Prague 1992

Hahnová E., Sudetonèmecká vzpomínání a zapomínání, Prague 2002

Hajachová Z., Oslavy narodenín prezidenta T. G. Masaryka na Slovensku, in: : I. Kušniráková et al., Vyjdeme v noci vo faklovom sprievode a rozsvietime svet, Bratislava 2012, pp. 171-185

Hájková D., 28 ř́ijen a jeho podoby, in: 1918 - model komplexního transformačního procesu?, ed. by L. Kostrbová, J. Malínská et al., Prague 2010, pp. 219-232

Halbwachs M., La mémoire collective, Paris 1950

Hawking S. W., A Short History of Time, transl. V. Karas. Prague 2003

Hilmera J., Stavovské národu!, Prague 1991

Hlavačka M., Mista pamèti a jejich 'misto' v historickém a společenském 'provozu, in: Pameét mist, událostí a osobností: historie jako identita a manipulace, M. Hlavačka, A. Marés, M. Pokorná et al. Prague 2011, pp. 10-21.

Husserl E., Přednášky k fenomenologii vnitřního časového vědomí, transl. V. Špalek and W. Hansel, Rychnov n. K. 1996

Kamenec I., Oslavy vzniku samostatnej Sklovenskej republiky v rokoch 1940-1945 in: I. Kušniráková et al., Vyjdeme v noci vo faklovom sprievode a rozsvietime svet, Bratislava 2012, pp. 208-224

Kárník Z., České zemè vére První republiky I, Prague 2000

Kárník Z., Malé déjiny Czechoslovak 1871-1939, Prague 2008

Kokoška S., Rok 1943 v Protektorátu Čechy a Morava, in: Válečný rok 1943 v okupované Evropě a v Protektorátu Čechy a Morava, Prague 2014 
Kovács É., O traumatickej pamäti Trianonu, in: M. Michela, L. Vörös et al., Rozpad Uhorska a Trianonská zmluva, K politikám pamäti na Slovensku a v Mad'arsku, Bratislava 2013, pp. 265-276

Kováč D., Štátne sviatky v Slovenskej republike ako 'miesta pamäti', in: Pamět' míst, událostí a osobností: historie jako identita a manipulace, M. Hlavačka, A. Marés, M. Pokorná et al. Prague 2011, pp. 105-118

Kula M., Nośniki pamięci historycznej, Warszawa 2002

Lipták L., Slovensko v dvadciatom storočí, 2nd ed., Bratislava 2011

Manová E., Slávenie trascendentna alebo oslavovanie moci? Sviatkovanie, slávnosti a oslavy očami historikov, in:

I. Kušniráková et al., Vyjdeme v noci vo faklovom sprievode a rozsvietime svet, Bratislava 2012, pp. 9-18.

Masaryk T. G., Světová revoluce, Prague 1925

Masslowski N., Šubrt J. et al., Kolektivní pamèt'. K teoretickým otázkám, Prague 2014

Nora P., Le Lieux de memoire I - III, 5. sv., Paris 1984-1992

Nora P., Mezi pamètí a historii, transl. by H. Thein, Cahiers du CEFRES NO. 13, Prague 1998

Pithart P., Devětaosmdesátý. Vzpomínky a přemýšlení: krédo, Prague 2009

Placák P., Češi, Němci a Slováci v roce 1929, Prague 2002

Pók A., Ungarische Interpretation der Gründung der Tschechoslowakei, in: 1918 - model komplexního transformačního procesu?, ed. by L.Kostrbová, J. Malínská et al., Prague 2010, pp. 29-38

Slovanství v národním životě Čechư a Slováků, Prague 1968

Slovenská otázka v 20. storočí, Bratislava 1997

Socha J., Promèna př́běhu aneb státní svátky, významné a památné dny v letech 1946-1990 in: „Historie Otázky - Problémy“ 2012, nr 4, vol.1, pp. 55-72

Státní politika vioči německé menšině v období konsolidace politické moci v Československu v letech 19181920. Edice pramenů, ed. by J. Harna, J. Šebek, Prague 2002

Stříbrný J., TGM a 28. říjen, Prague 1938

Šedivý I., Victory Day 28. October 1918? La naissance de la Tchécoslovaquie, le contexte de la Grande Guerre et ses consequences, in: La Tchécoslovaquie sismographe de l'Europe au XXe siécle, ed. by A. Marés et al. Paris 2009, pp. 35-41

Škrábek J., Včerejší strach, Prague 2002

Šubrt J., Vinopal J. et al., Historické vědomí obyvatel České republiky perspektivou sociologického výzkumu, Prague 2013

Waic M., Tělesná výchova a sport v politickém životě meziválečného Československa, in print.

Wright, von, H., Explanation and Understanding,London 1974

Zídek P., Hana Benešová, Prague 2014

[strona WWW]: http://novepribehy.webnode.cz/album/rijen-oktober/p1060237-jpg [dostęp: 31/03/16]

[strona WWW]: http://uzhss.webnode.cz [dostęp: 31/03/16]

[strona WWW]: http://www.abscr.cz/cs/vystava-k-vyroci-republiky[dostęp: 31/03/16]

[strona WWW]: http://www.csfd.cz/film/224593-jak-pejsek-s-kocickou-slavili-28-rijen/[dostęp: 31/03/16]

[stronaWWW]:http://www.epravo.cz/vyhledavani-aspi/?Id=3865\&Section=1\&IdPara=1\&ParaC=2 [dostęp: 31/03/16]

[strona WWW]: http://www.klubtgm.cz/aktualne.ph[dostęp: 31/03/16]

[strona WWW]: http://www.psp.cz/docs/texts/constitution_1920.html[dostęp: 31/03/16]

[strona WWW]: http://www.psp.cz/eknih/1920ns/ps/tisky/t5061_00.htm[dostęp: 31/03/16]

[strona WWW]: http://www.psp.cz/eknih/1948ns/tisky/t0587_00.htm[dostęp: 31/03/16]

[strona WWW]: http://www.psp.cz/sqw/sbirka.sqw?cz=248\&r=1946[dostęp: 31/03/16]

[strona WWW]: http://www.psp.cz/sqw/sbirka.sqw?cz=56\&r=1975[dostęp: 31/03/16]

[strona WWW]: http://www.psp.cz/sqw/sbirka.sqw?cz=93\&r=1951[dostęp: 31/03/16]

[strona WWW]: http://www.rozhlas.cz/archiv/rozhlasovyrok/_zprava/jak-pejsek-s-kocickou-slavili-28-rijen--1274854 [dostęp: 31/03/16]

[strona WWW]: http://www.zakonyprolidi.cz/cs/1945-30[dostęp: 31/03/16] 